\title{
MSC wt Allele
}

National Cancer Institute

\section{Source}

National Cancer Institute. MSC wt Allele. NCI Thesaurus. Code C54327.

Human MSC wild-type allele is located in the vicinity of $8 \mathrm{q} 21$ and is approximately $3 \mathrm{~kb}$ in length. This allele, which encodes musculin protein, is involve in both the modulation of transcription by RNA polymerase II and antigen-dependent differentiation in B cells. 